\title{
PERANCANGAN SISTEM INFORMASI PENERIMAAN SISWA BARU BERBASIS WEB PADA PKBM BHAKTI SEJAHTERA
}

\author{
Aris $^{1}$ \\ Ryan Anggara ${ }^{2}$ \\ Zaimi Akhmad Zamzami ${ }^{3}$ \\ Alumni STMIK PGRI Jurusan Sistem Informasi Tangerang ${ }^{1}$, STMIK Raharja Jurusan Teknik \\ Informatika $^{2}$, STMIK Raharja Jurusan Sistem Informasi ${ }^{3}$ \\ Jl. Perintis Kemerdekaan II, Tangerang ${ }^{l}$, Jl. Jendral Sudirman No. 40, Modernland, Tangerang ${ }^{2,3}$ \\ Email : $\underline{\text { aris@raharja.info }{ }^{1)}}$, ryan.anggara@raharja.info ${ }^{2)}$, zaimiakhmadzamzami@raharja.info
}

\begin{abstract}
Bhakti Sejahtera Tangerang is a school located in the district of Tangerang which have the aim of helping the government program in the field of non-formal education and produce qualified young generation, these schools also strive to provide a good service for this school masarakat.Namun also has disadvantages mainly the new admissions system that exists. New admissions system that existed at this school has been using a computer but still using a simple application, so often there is a delay in the presentation of information, so there needs to be a new system that can improve the existing system. To resolve this problem, the school needs to use the new system with a computerized system that has a better database to store its data. With a computerized system that better data processing will be more efficient and to minimize errors in the data pengimputan. Thus the new admissions system that there will be better and can improve service to masarakat who want to registerKeywords : Mutimedia, Computer Generated Imagery, Software, Computer, Technology.
\end{abstract}

Keywords: Computerized, Registration, Students

\section{ABSTRAK}

PKBM Bhakti Sejahtera Tangerang adalah sebuah sekolah yang terletak di kecamatan Kota Tangerang yang mempunyai tujuan membantu program pemerintah dalam bidang pendidikan non formal dan menghasilkan generasi muda yang berkualitas, Sekolah ini juga selalu berusaha memberikan pelayanan yang baik untuk masarakat.Namun sekolah ini juga memiliki kendala terutama dalam system penerimaan siswa baru yang ada. System penerimaan siswa baru yang ada pada sekolah ini sudah menggunakan komputer namun masih menggunakan aplikasi yang sederhana, sehingga sering terjadi keterlambatan dalam penyajian informasi, sehingga perlu ada system baru yang dapat menyempurnakan system yang ada. Untuk menyelesaikan permasalahan ini maka sekolah perlu menggunakan system yang baru dengan system terkomputerisasi yang memiliki database yang lebih baik untuk menyimpan datanya. Dengan sistem terkomputerisasi yang lebih baik pemprosesan data akan lebih efisien dan dapat meminimalisir kesalahan dalam pengimputan data. Dengan demikian sistem penerimaan siswa baru yang ada nantinya akan lebih baik lagi dan dapat meningkatkan pelayanan kepada masarakat yang ingin mendaftar.

Kata Kunci: Komputerisasi, Pendaftaran, Siswa 


\section{PENDAHULUAN}

Dunia pendidikan yang semakin pesat menjadi kebutuhan yang sangat penting diperlukan bagi siapa saja. Sistem penerimaan siswa baru pada sekolah adalah hal yang sangat penting dilakukan untuk mendata siswa/siswi baru pada sekolah tersebut. Perguruan Tinggi Raharja Tangerang sebagai lembaga pendidikan berusaha untuk membantu mahasiswa dalam mendapatkan ilmu dan pengetahuan dengan mengembangkan potensi diri.Dalam jaringan internet ada jutaan bahkan miliaran situs yang berbentuk web. Website bukan hanya situs biasa saja, tetapi menjadi tempat untuk manusia dapat saling berinteraksi. Web telah menjadi antar muka pemakai untuk aplikasi basis data, dan web telah menjadi sistem informasi tersebar, dimana pemakai tidak perlu download perangkat lunak khusus untuk mengakses informasi.PKBM Bhakti Sejahtera merupakan sekolah non formal di Kecamatan Sukamulya. Bertambahnya siswa yang mendaftarkan diri, maka pihak sekolah pun berusaha memberikan pelayanan yang lebih baik khususnya dalam proses penerimaan siswa baru, sistem komputerisasi yang bertujuan agar dapat mengolah data dengan sebaikbaiknya, maka dituntut adanya alat yang membantu dalam proses ini agar lebih cepat, efisisen dan efektif.Latar belakang penelitian ini adalah bagaimana peneliti ingin mengetahui sistem yang sedang berjalan selama ini khususnya dalam penerimaan siswa/siswi baru, karena dengan pertumbuhan yang begitu pesat pengelolaan mengenai penerimaan siswa/siswi baru harus didukung dengan sistem informasi yang cukup baik agar tidak mengalami hambatan terutama dalam pencatatan data siswa/siswi baru, kurangnya pendataan transaksi yang di terima mengakibatkan laporan penerimaan siswa/siswi baru setiap tahunnya mengalami keterlambatan.

\section{PERMASALAHAN}

Berdasarkan latar belakang masalah di atas, maka dirumuskan beberapa masalah, yaitu :

a. Bagaimana proses pengolahan data penerimaan siswa baru?

b. Bagaimana proses penyimpanan data siswa agar tetap aman dan dapat dengan mudah di akses?

c. Apa manfaat dari rancangan sistem penerimaan siswa baru berbasis web?

\section{LITERATUR REVIEW}

a. Banyak penelitian yang sebelumnya dilakukan mengenai Penerimaan Siswa Baru Berbasis Web. Dalam upaya pengembangannya perlu dilakukan studi pustaka sebagai salah satu dari penerapan metode penelitian yang akan dilakukan. Diantaranya adalah Pengumpulan Data ( Observasi Research ), Wawancara ( Interview Research) ,dan Studi Pustaka ( Library Research ) mengidentifikasikan metode yang pernah dilakukan, meneruskan penelitian sebelumnya, serta mengetahui orang lain yang spesialisasi dan area penelitiannya sama dibidang ini. Beberapa Literature review tersebut adalah sebagai berikut :

1. Menurut jurnal Aris dan rekan, yang berjudul "APLIKASI PROTOTYPE SISTEM INFORMASI PENERIMAAN SISWA BARU PADA SMK YUPPENTEK 1 TANGERANG BERBASIS WEB'.Dalam perkembangan dunia pendidikan yang begitu pesat, sistem siswa baru sekolah adalah hal yang sangat penting dilakukan untuk mendata siswa yang pada sekolah tersebut. Ketepatan, keakuratan dan kecepatan dalam layanan penerimaan siswa baru merupakan faktor utama untuk mendapatkan hasil yang tepat, untuk suatu fasilitas atau sarana yang sangat di butuhkan untuk menunjang dan membantu melaksanakan pengolahan data yang tepat. Komputer adalah salah 
satu alat yang dapat membantu untuk mempermudah dan mempercepat di dalam menyelesaikan tugas-tugas tersebut. Penulis melakukan penelitian khususnya pada system penerimaan siswa baru, analisa terhadap system yang sedang berjalan, cara kerja system , masalah yang ditemukan pada system yang berjalan. tujuannya untuk lebih mempermudah dalam mengakses datadata yang diperlukan oleh pihal-pihak yang membutuhkannya. Dalam perkembanganya system penerimaan siswa baru dapat dilakukan secara online yaitu dengan mengggunakan website yang dibangun khusus untuk pendaftaran.Dari system yang dibangun dapat menggambarkan proses awal siswa melakukan pendaftaran dari mulai mengisi data pribadi sampai melakukan ujian tes seleksi masuk,dan pada sekolahan dapat melakukan pendataan dan penginputan nilai ujian seleksi masuk yang sudah dapat berjalan.

Melihat pentingnya system penerimaan siswa baru yang berbasis web dengan system online maka dapat kita ambil permasalahan yang menjadi kendala system tersebut dibangun pada SMK Yupentek 1, diantaranya bagaimana proses pengolahan data layanan penenerimaan siswa baru pada SMK Yuppentek 1 Tangerang apakah sudah tepat dan akurat untuk proses pengolahan datanya, termasuk pengolahan data siswa yang mendaftar.Dan bagaimana proses penyimpanan data calon siswa baru SMK Yuppentek 1 Tangerang agar tetap aman dan dapat dengan mudah di akses,yang artinya pada saat data tersebut dibutuhkan apakah bisa di lakukan pendataan kembali. Serta bagaimana rancangan sistem penerimaan siswa baru yang diusulkan pada panitia SMK Yuppentek 1 Tangerang agar dalam pengelolahan system penerimaan dapat menjadi lebih baik dari segala segi aspek bidang teknologi computer.[9]

2. Menurut jurnal Wardiyanto rekan, yang berjudul "SISTEM PENERIMAAN
SISWA BARU SECARA ONLINE PADA SMP NEGERI 2 RAKIT “ menjelaskan bahwa, Peran sistem informasi sekolah di kalangan pendidikan mempunyai peranan yang sangat penting untuk mendukung kinerja akademis di sekolah. SMP Negeri 2 Rakit Kabupaten Banjarnegara memiliki sistem akademis yang menangani data penerimaan siswa baru. Sistem informasi akademis yang disediakan di SMP Negeri 2 Rakit masih mengalami kesulitan jika siswa maupun guru melihat data- data peserta calon siswa. Dengan pertimbangan diatas penulis mencoba untuk mencari solusi agar sistem informasi sekolah tersebut dapat menangani seleksi pendaftaran calon siswa baru di sekolah dengan sebaik-baiknya. Solusi yang akan dikembangkan adalah dengan merancang aplikasi Sistem Penerimaan Siswa Baru Secara Online Pada SMP Negeri 2 Rakit. Dalam membuat sistem PSB, metode yang digunakan adalah metode waterfall. Langkah-langkah metode, insterumen penelitian, analisa, perancangan sistem, serta hasil kesimpulan sistem yang diusulkan mampu mengatasi keterbatasan sistem manual, kesalahan input data calon siswa, memudahkan pelaporan daftar calon siswa serta memudahkan siswa untuk mengakses PSB secara online.[10]

\section{PEMBAHASAN}

\section{Teori Pendukung \\ Definisi Sistem}

Sebuah sistem yang tepat guna akan memberikan dampak yang positif bagi suatu perusahaan dalam pencapaian sasaran serta tujuan perusahaan. sistem terdapat beberapa pandangan menurut para ahli, diantaranya :

Pengertian sistem yang dapat didefinisikan dengan pendekatan prosedur yaitu kumpulan dari prosedur prosedur yang mempunyai tujuan tertentu. Sistem juga dapat di definisikan dengan pendekatan komponen yaitu 
kumpulan dari komponen yang saling berhubungan satu dengan yang lainnya membentuk satu kesatuan untuk mencapai tujuan tertentu.[4]

Secara umum, definisi sistem adalah kumpulan bagian-bagian atau subsistemsubsistem yang disatukan dan dirancang untuk mencapai suatu tujuan tertentu.

\section{Karakteristik Sistem}

Suatu sistem mempunyai karakteristik atau sifat - sifat tertentu antara lain :[5]

1. Komponen Sistem (components)

Suatu sistem harus terdiri dari sejumlah komponen yang saling berinteraksi, artinya saling bekerja sama membentuk satu kesatuan. Komponen sistem dapat berupa subsistem-subsistem atau bagianbagian sistem.

2. Batasan Sistem (boundary)

Batasan sistem (boundary) merupakan daerah yang membatasi antara suatu sistem dengan sistem yang lainnya atau dengan lingkungan luarnya.Batasan sistem ini memungkinkan suatu sistem dipandang sebagai satu kesatuan, batasan sistem menunjukan ruang lingkup (scope) sistem itu sendiri.

3. Lingkungan Luar (environments)

Lingkungan luar sistem (environments) yaitu apapun di luar batas sistem yang dapat mempengaruhi operasi sistem.Lingkungan luar sistem dapat bersifat menguntungkan dan dapat juga bersifat merugikan.Lingkungan luar sistem yang menguntungkan merupakan energi dari sistem tersebut dengan demikian harus tetap dijaga dan dipelihara.Lingkungan luar sistem yang merugikan harus ditahan dan dikendalikan.

4. Penghubung (interface)

Penghubung sistem (interface) merupakan media penghubung antara satu subsistem dengan subsistem yang lainnya.Melalui penghubung ini memungkinkan sumber daya mengalir dari subsistem yang satu ke subsistem yang lainnya.

5. Tujuan atau Sasaran (goals)

Suatu system dikatakan berhasil bila mengenai tujuannya. Kalau suatu sistem tidak mempunyai tujuannya, maka operasi sistem tidak ada gunanya.

\section{Syarat-Syarat Sistem}

Syarat-syarat yang harus dimiliki oleh suatu sistem, yaitu:[2]

1. Sistem harus dibentuk untuk menyelesaikan suatu tujuan.

2. Elemen sistem harus mempunyai rencana yang ditetapkan.

3. Adanya hubungan diantara elemen sistem.

4. Unsur dasar dari proses (arus informasi, energi, dan material) lebih penting daripada elemen sistem.

\section{Kriteria Sistem Yang Baik}

\section{Ketersediaan}

a. Dokumentasi data lengkap, dimana setiap aktifitas bisnis dapat terekam dalam sebuah sistem informasi.

b. Meminimalkan kegagalan sistem, mencegah agar sistem tersebut dapat berjalan sesuai dengan harapan.

2. Keamanan

a. Pemberian password, salah satu bentuk keamanan sebuah sistem, diperlukan security password untuk mencegah terjadinya penyalahgunaan data.

b. Posisi komputer yang aman, hal ini lebih mengarah tentang tata letak komputer dan jaringan. 
c. Pasang alarm keamanan, untuk mencegah pencurian perangkat keras. Seperti monitor, cpu (central processing unit), dll.

d. Data control, pemantauan data secara rutin dapat mengurangi resiko masalah keamanan data yang disimpan pada sebuah sistem.

3. Dapat dipelihara

a. Pengukuran kinerja sistem dan peninjauan berkala sistem, dua hal ini saling berhubungan. Karena peninjauan sistem secara rutin dapat digunakan untuk memantau data sekaligus mengukur kinerja sistem yang sedang berjalan. Sehingga manajemen sistem informasi data mengetahui apa yang akan dilakukan terhadap sistem tersebut kedepannya.

\section{Integritas}

a. Verifikasi data, proses pengecekan data saat data dimasukkan hingga keluar menjadi sebuah informasi. Verifikasi data membutuhkan waktu dan tenaga, yang dilakukan oleh manajemen sistem.

b. Pengecekan data rangkap, untuk mengurangi redundansi data (data rangkap) perlu dilakukan secara bertahap. Bisa juga dikategorikan sebagai data kontrol. Hanya saja hal ini bertujuan untuk memanajemen sistem database.

\section{KONSEP DASAR INFORMASI}

\section{Definisi Informasi}

Informasi ibarat darah yang mengalir didalam tubuh manusia, maksud dari kalimat tersebut yaitu bahwa informasi yang sangat penting pada suatu organisasi. Informasi dapat diartikan menurut para ahli sebagai berikut:[7]

1.Informasi (Information) adalah data yang diolah menjadi bentuk yang berguna bagi para pemakainya

2.Menurut Leitel dan Devis dalam bukunya: "Accounting Information System" menjelaskan bahwa informasi merupakan data yang diolah menjadi bentuk yang lebih berguna serta lebih berarti bagi yang menerimanya

3.Sistem Informasi (information system) adalah sekumpulan komponen yang saling berhubungan, mengumpulkan atau mendapatkan, memproses, menyimpan dan mendistribusikan informasi untuk menunjang pengambilan keputusan dan pengawasan dalam suatu organisasi serta membantu manajer dalam pengambilan keputusan .

\section{Kualitas Informasi}

Terbentuknya informasi yang dihasilkan dari proses pengolahan data hingga sampai ke pengguna informasi tersebut, maka informasi tersebut haruslah mempunyai kualitas yang baik. Dan kualitas informasi (quality of information) Untuk dapat berguna dengan baik, maka informasi harus didukung oleh tiga pilar sebagai berikut:[3]

1.Tepat kepada orangnya atau Relevan (Relevancy)

Berarti informasi tersebut mempunyai manfaat untuk pemakainnya. Relevan informasi untuk tiap-tiap orang satu dengan yang lain berbeda.Tepat waktu (TimeLines)

Berarti informasi yang datang pada penerimaan tidak boleh terlambat, informasi yang sudah usang tidak akan mempunyai nilai lagi, karena informasi merupakan landasan didalam pengambilan keputusan.

\section{Tepat nilainya atau Akurat (Accurate)}

Berarti informasi harus bebas dari kesalahan-kesalahan. Akurat juga berarti Informasi harus jelas mencerminkan maksudnya. Informasi harus akurat karena dari sumber informasi ke penerima kemungkinan banyak terjadi. 


\section{Nilai Informasi}

Fungsi informasi yang dibutuhkan untuk pengambilan keputusan terkadang diperlukan dengan proses yang cepat dan tidak terduga. Hal itu mengakibatkan penggunaan informasi hanya berdasarkan perkiraan-perkiraan serta informasi yang apa adanya. Dengan perlakuan seperti ini mengakibatkan keputusan yang diambil tidak sesuai dengan yang diharapkan.Oleh karena itu untuk memperbaiki keputusan yang telah diambil maka pencarian informasi yang lebih tepat perlu dilakukan.Suatu Informasi memiliki nilai karena informasi tersebut dapat menjadikan keputusan yang baik serta menguntungkan dan memiliki nilai informasi yang tepat. [1]

Nilai suatu informasi dapat ditentukan berdasarkan sifatnya. Tentang 10 sifat yang dapat menentukan nilai informasi, yaitu sebagai berikut :

1.Kemudahan dalam memperoleh Informasi memiliki nilai yang lebih sempurna apabila dapat diperoleh secara mudah. Informasi yang penting dan sangat dibutuhkan menjadi tidak bernilai jika sulit diperoleh.

2.Sifat luas dan kelengkapannya Informasi mempunyai nilai yang lebih sempurna apabila mempunyai lingkup/cakupan yang luas dan lengkap. Informasi sepotong dan tidak lengkap menjadi tidak bernilai, karena tidak dapat digunakan secara baik.

\section{Ketelitian (accuracy)}

Informasi mempunyai nilai yang lebih sempurna apabila mempunyai ketelitian yang tinggi/akurat. Informasi menjadi tidak bernilai jika tidak akurat, karena akan mengakibatkan kesalahan pengambilan keputusan.

4.Kecocokan dengan pengguna (relevance)

Informasi mempunyai nilai yang lebih sempurna apabila sesuai dengan kebutuhan penggunanya. Informasi berharga dan penting menjadi tidak bernilai jika tidak sesuai dengan kebutuhan penggunanya, karena tidak dapat dimanfaatkan untuk pengambilan keputusan.

\section{Ketepatan waktu}

Informasi mempunyai nilai yang lebih sempurna apabila dapat diterima oleh pengguna pada saat yang tepat. Informasi berharga dan penting menjadi tidak bernilai jika terlambat diterima/usang, karena tidak dapat dimanfaatkan pada saat pengambilan keputusan.

\section{Kejelasan (clarity)}

Informasi yang jelas akan meningkatkan kesempurnaan nilai informasi. Kejelasan informasi dipengaruhi oleh bentuk dan format informasi.

\section{Keluwesannya (fleksibilitas)}

Nilai informasi semakin sempurna apabila memiliki fleksibilitas tinggi. Fleksibilitas informasi diperlukan oleh para manajer/pimpinan pada saat pengambilan keputusan.

8. Dapat dibuktikan

Nilai informasi semakin sempurna apabila informasi tersebut dapat dibuktikan kebenarannya. Kebenaran informasi bergantung pada validitas data sumber yang diolah. 
9. Dapat diukur

Informasi untuk pengambilan keputusan seharusnya dapat diukur agar dapat mencapai nilai yang sempurna.

Berdasarkan latar belakang masalah di atas, maka dirumuskan beberapa masalah, yaitu :

a. Bagaimana proses pengolahan data penerimaan siswa baru?

b. Bagaimana proses penyimpanan data siswa agar tetap aman dan dapat dengan mudah di akses?

c. Apa manfaat dari rancangan sistem penerimaan siswa baru berbasis web?

\section{Metodologi Design Sistem Rancangan Sistem}

Pada tahap ini, peneliti melakukan desain informasi yang akan dibangun dengan tahapan teknik sebagai berikut :

\section{Project Definition Study}

Dalam tahap ini ditentukan kebutuhankebutahan user dan kegunaankegunaan dari pada sistem yang akan digunakan.

2. Sistem Analisis and Design

Dalam tahap ini seluruh deskripsi sistem dipersiapkan.

3. Detail Design and Programming

Tahap ini memfokuskan pada komponen-komponen intern sistem dan tahap pengembangan programprogram komputer diperlukan untuk membentuk sistem.

4. Sistem Test

Sistem yang telah dibangun, dipelajari dengan berbagai test untuk dilakukan koreksi-koreksi dan penyempurnaan sesuai dengan kebutuhan user seperti tertuang dalam dokumen yang ada.

5. Conversion

Dalam tahap ini sistem telah ditest beserta prosedur-proseduroprasi diputuskan untuk dilakukan oprasi pengolahan penuh.

6. Operational
Dalam tahap ini dilakukan proses secara teratur, perubahan program (kecil-kecilan) dan maintenance sesuai dengan adanya perubahan dalam kebijakan atau proseur organisasi atau perusahaan.

7. Post Implementasi

Dilakukan pengkajian apakah sistem telah melakukan pekerjaan-pekerjaan sesuai kebutuhan user secara utuh. Bila masih ada yang akan ditambahkan karena adanya kebijakan organisasi/perusahaan.

\section{Implementasi}

Dalam metode perancangan digunakan metode berorientasi objek, Unified Modeling Language (UML) dengan menggunakan tool Visual Paradigm 6.4. PHP sebagai scriptnya $M y S Q l$ untuk databasenya serta Macromedia Dreamweaver 8 untuk membuat rancangan program.

\section{Diagram yang di Usulkan menggunakan UML}

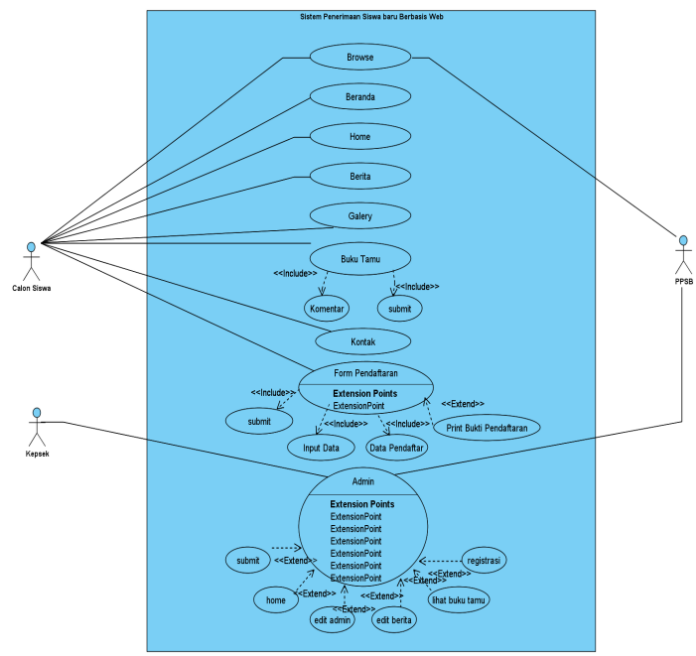

Gambar 1. Use Case Diagram yang diusulkan

Berdasarkan Gambar 1 Use Case Diagram yang diusulkan terdapat :

a. 3 Actor yang melakukan kegiatan, diantaranya calon siswa, admin dan Kepala Sekolah. 
b. 21 Use case yang biasa dilakukan oleh actor-actor tersebut.

c. 3 Include yaitu submit, input data dan data pendaftar

d. 7 Extend yang menspesifikan use case

\section{Sequence Diagram yang diusulkan :}

\section{Admin}

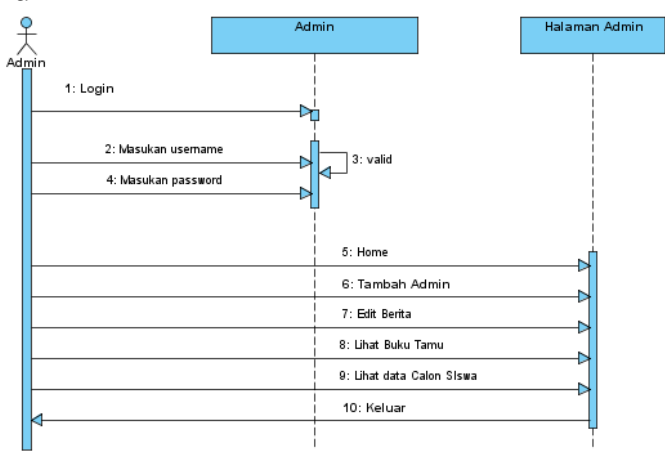

Gambar 2. Sequence Diagram Admin yang diusulkan

Berdasarkan Gambar 2 Sequence Diagram : Admin yang diusulkan terdapat :

a. 2 LifeLine antarmuka yang saling berinteraksi, diantaranya Admin, Halaman Admin.

b. 1 actor yang melakukan kegiatan, yaitu admin.

c. 10 message diantaranya membuka login, masukan user name \& password, valid, home, Tambah admin, Edit berita, lihat buku tamu, lihat data calon siswa, keluar.

3.Sequence Diagram yang diusulkan : Pendaftaran

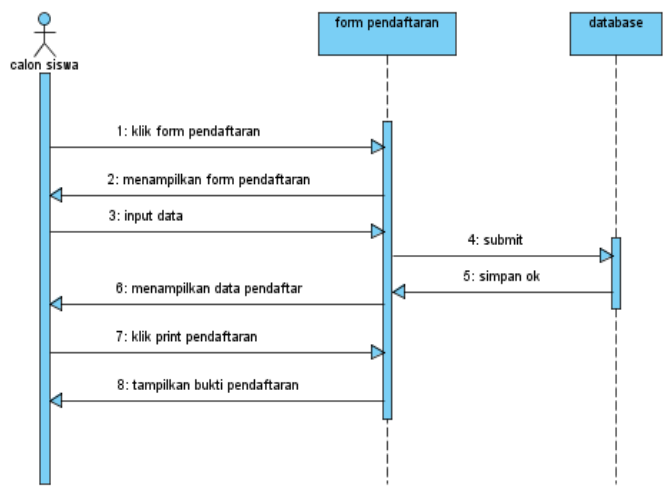

Gambar 3. Sequence Diagram Pendaftaran yang diusulkan
Berdasarkan Gambar 3 Sequence Diagram Pendaftaran yang diusulkan terdapat :

a. 2 LifeLine antarmuka yang saling berinteraksi, yakni form pendaftaran, database

b. 1 actor yang melakukan kegiatan, yaitu calon siswa.

c. 8 message, diantaranya klik form pendaftaran, manampilkan form pendaftaran, input data, submit, simpan ok, menampilkan data pendaftar, klik print bukti pendaftaran, tampilkan bukti pendaftaran.

\section{Actifity Diagram Pendaftaran Calon siswa yang diusulkan}

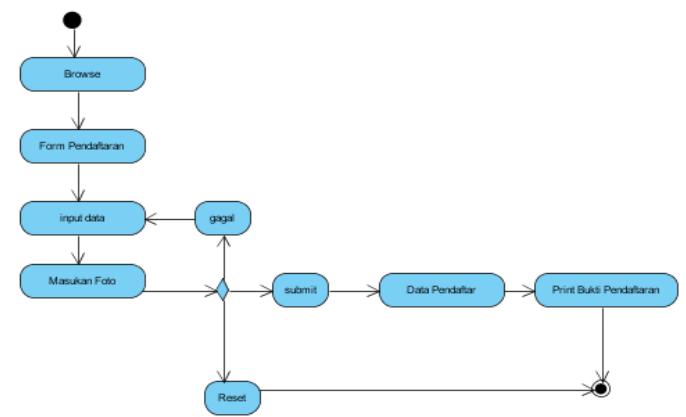

Gambar 4. Actifity Diagram calon siswa

Berdasarkan Gambar 4 Actifity Diagram calon siswa yang diusulkan terdapat :

a. 1 Initial Node, objek yang diawali.

b. 1 Decision node satu aliran yang berubah menjadi beberapa aliran.

c. 9 action, state dari sistem yang mencerminkan eksekusi dari suatu aksi diantaranya browse, pilih menu form pendaftaran, input data, masukan foto, gagal, submit, reset, data pendaftar, print bukti pendaftaran, keluar.

d. 1 Final State, objek yang di akhiri.

\section{Rancangan struktur database}

Rancangan database digunakan sebagai media penyimpanan data yang dipergunakan dalam aplikasi ini dan database membantu pemrograman dalam menampilkan data. Pada tabel ini akan 
dijelaskan nama field, lebar, dan keterangan mengenai database tersebut.

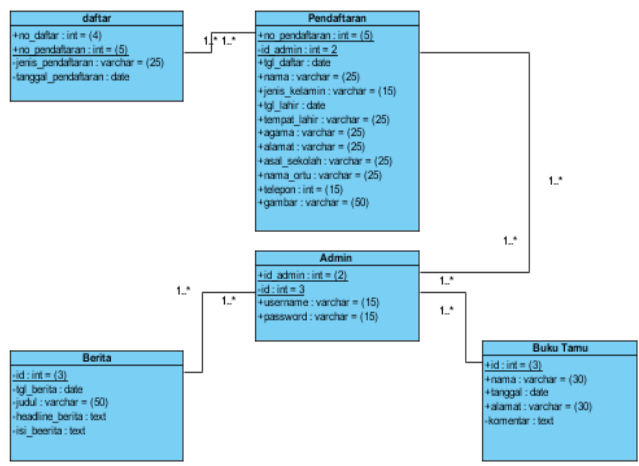

Gambar 5. Class Diagram yang diusulkan

Berdasarkan gambar 5. Class Diagram yang diusulkan terdapat:

a. 5 class, himpunan dari objek-objek yang berbagi atribut serta operasi yang sama diantaranya : daftar dan pendaftaran , Admin, berita dan buku_tamu.

b. 4 Association, hubungan antara objek satu dengan objek lainnya yang mempunyai nilai.

\section{Rancangan Tampilan Sistem Yang Diusulkan}

\section{a.Tampilan Halaman Menu Utama}

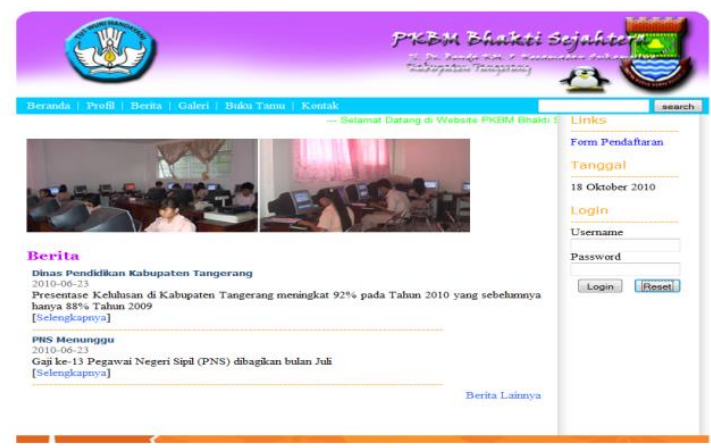

Gambar 6. Tampilan Halaman Menu Utama

Pada tampilan menu utama atau index berada pada halaman home, pada halaman ini terdapat beberapa link diantaranya home, profil, galery, buku tamu, info prndaftaran, formulir pendaftaran, dan login admin yang akan menuju ke masing-masing halaman dari link tersebut. Pada halaman home ini juga terdapat informasi seputar PKBM Bhakti Sejahtera.

\section{b.Tampilan layar profil}

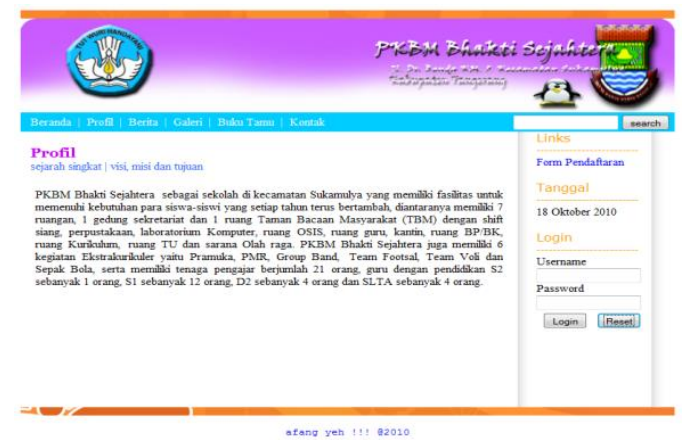

Gambar 7. Tampilan layar menu profil

Pada gambar dibawah ini.Pada layar profil terdapat gambaran umum, sejarah singkat, visi dan misi, seperti yang terlihat .

\section{c.Tampilan Berita}

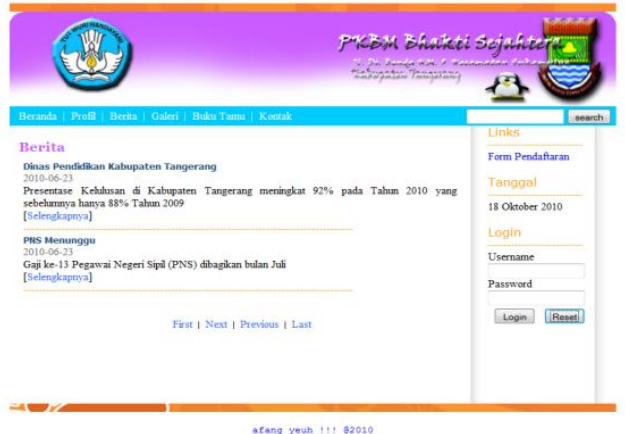

Gambar 8.Tampilan layar menu berita

Pada gambar 8 merupakan menu yang ebrisikan tentang informasi sekitar kegiatan di PKBM Bhakti Sejahtera baik penerimaan siswa baru. 


\section{d.Tampilan Menu pendaftaran}

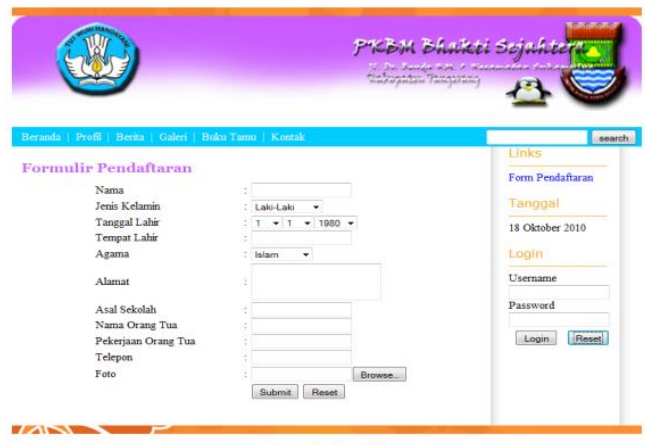

Gambar 9.Tampilan layar pendaftaran

Pada menu pendaftaran terdapat formform yang akan diisi data calon siswa PKBM Bhakti Sejahtera, form-form tersebut berisi tentang biodata calon siswa PKBM Bhakti Sejahtera. Setelah mengisi formulir pendaftaran calon siswa diisi dengan lengkap dan benar tekan tombol submit.

\section{e.Tampilan Layar Data Pendaftar}

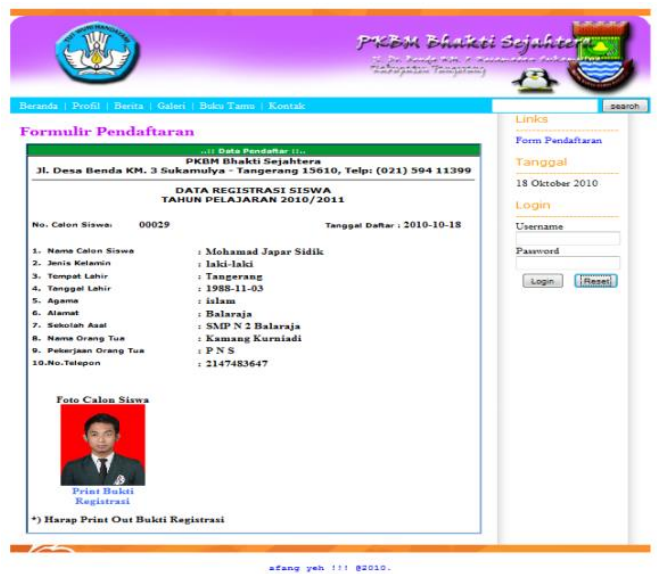

Gambar 10. Tampilan Layar Data Pendaftar

Setelah mengisi formulir pendaftaran calon siswa diisi dengan lengkap dan benar tekan tombol submit maka akan tampil layar data calon siswa seperti terlihat pada gambar adibawah ini.

\section{f.Tampilan Print bukti pedaftaran}

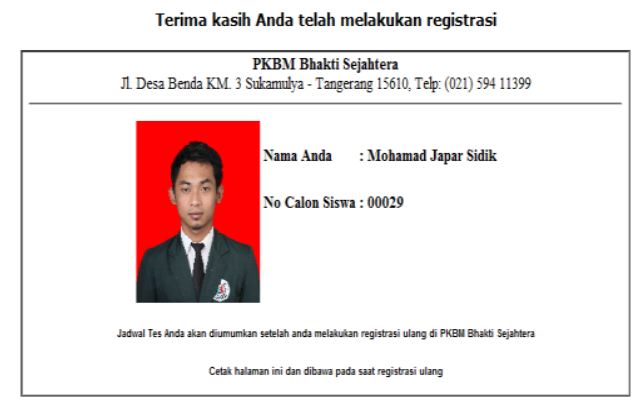

Gambar 11.Tampilan Print Bukti Pendaftaran

Setelah melakukan pendaftaran diharapkan mencetak bukti pembayaran ini sebagai tanda bukti pendaftaran.

\section{g.Tampilan Menu Administrator}

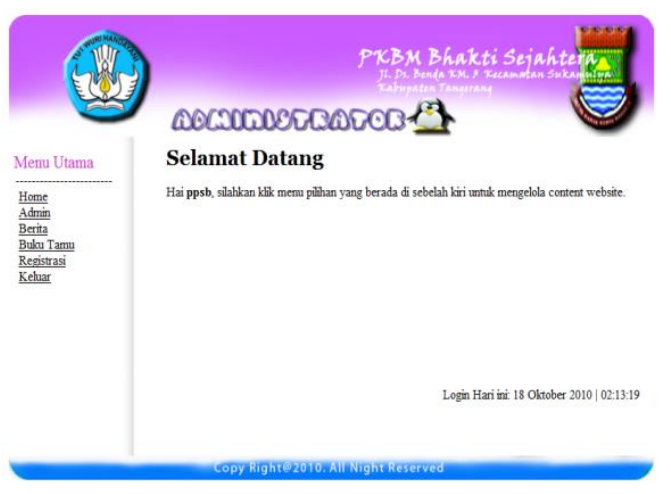

Gambar 12. Tampilan Layar Administrator

Pada Gambar 12 khusus untuk Administrator karena di halaman ini terdapat isi database yang bisa di hapus dan dilihat secara detail calon siswa PKBM Bhakti Sejahtera. Karena halaman ini bersifat rahasia sehingga di berikan halaman login, sehingga tidak sembarang orang yang bisa mengaksesnya. 


\section{h.Tampilan Registrasi/Data Calon Siswa}

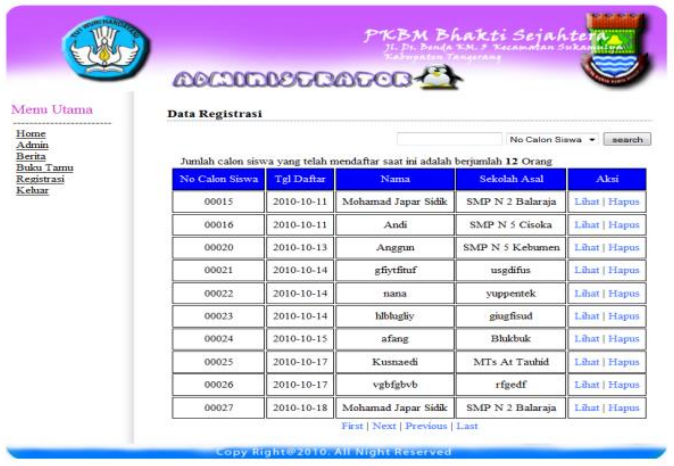

Gambar 13. Tampilan Data calon siswa

Pada gambar 13 halaman administrator untuk menampilkan tampilan pencarian data calon siswa PKBM Bhakti Sejahtera.

\section{KESIMPULAN}

Setelah mempelajari permasalahan yang dihadapi berdasarkan hasil penelitian dan pengamatan yang telah dilakukan, pada bagian penerimaan siswa baru, maka dapat diambil kesimpulan yaitu :

a. Sistem penerimaan siswa baru yang berjalan pada PKBM Bhakti Sejahtera Tangerang saat ini masih sudah menggunakan komputer namun baru sebatas office dan karenanya memerlukan waktu yang cukup lama dalam proses penyimpanan data.

b.Agar sistem yang berjalan bisa berjalan lebih efektif dan efisien maka diperlukan sistem komputerisasi diantaranya berbasis web.

c. Sistem penerimaan siswa baru PKBM Bhakti Sejahtera Tangerang yang dihasilkan, mempunyai beberapa fungsi yaitu pendaftaran, profil, buku tamu, berita, galeri dan kontak. Manfaat yang didapat dari sistem komputer melalui website adalah dapat mempermudah proses pendaftaran juga untuk memperkenalkan sistem website pada calon siswa.
Setelah sistem dapat diterapkan dan diimplementasikan dengan baik maka tidak menutup kemungkinan untuk dilakukan suatu pengembangan sistem yang baru, agar kekurangan pada sistem ini dapat diperbaiki maupun ditambah serta agar dapat tetap sejalan dengan perkembangan ilmu teknologi yang semakin canggih.

\section{DAFTAR PUSTAKA}

[1] Hartono,. "SPSS 16, O Analisis Data Statistika dan Penelitian", Yogyakarta Jogiyanto, H.M. 1988. Pengenalan Komputer, Dasar Ilmu Komputer, Pemograman, Sistem Informasi, dan Intelegensi Buatan. Yogyakarta, 2008

[2] Davis, Gordon B. “ Kerangka Dasar Sistem Informasi Manajemen". 2008

[3]Yogiyanto, "Sistem Informasi Berbasis Komputer" , Penerbit BPFE, Yogyakarta , 2008

[4]Adi Nugroho, "Analisa dan Perancangan Sistem Informasi dengan metologi". Yudistira.Bandung, 2008

[5] Agus Mulyanto "Sistem Informasi Konsep Dan Aplikasi" . Penerbit Pustaka Pelajar. Yogyakarta, 2009

[6] Meller Randy,"Pengembangan Sistem Informasi, Informatika”, Jakarta, 2008

[7]Kusrini , Tuntunan Praktis Membangun Sistem Informasi Dengan Visual Basis dan Microsoft SQL Server, Penerbit : Andi, 2007

[8] Henderi. Analisis And Design With Unified Modeling Languange (UML). STMIK Raharja , Tangerang, 2007

[9] Aris Dkk, “APLIKASI PROTOTYPE SISTEM INFORMASI PENERIMAAN SISWA BARU PADA SMK YUPPENTEK 1 TANGERANG BERBASIS WEB "Jurnal Teknomedia AMIKOM Yogyakarta Vol. 4 NO. 2 Tahun 2015 
[10]Wardiyanto Dkk, "SISTEM

Tugas Akhir, Akademi Teknik

PENERIMAAN SISWA BARU

Telekomunikasi Sandhy Putra

SECARA ONLINE PADA SMP

Purwokerto,2010

NEGERI 2 RAKIT "Jurnal Laporan 